\title{
Learning to Share: Explaining the Conditions under Which States Delegate Governance
}

\section{Aila M. Matanock}

\begin{abstract}
A potential solution for weak or failing states is to enact a delegation agreement whereby a host relinquishes authority over some governance function to an external actor. Through case studies in Melanesia, I find that these arrangements can be implemented as treaties, rather than contracts, so that the external actor remains somewhat exempt from the normal procedure or law of the host state. I also generate hypotheses about the conditions under which host states and external actors enact these self-enforcing equilibria: host states request these agreements either where a major law and order problem leads to a loss of monopoly on the use of force, or where extortion or corruption leads to budgetary crisis. External actors agree to them only under the latter circumstances since this makes the reputational and actual costs of the mission lower, as judged against alternative methods for resolving the problem, and where that state also poses a specific transnational security threat.
\end{abstract}




\title{
Learning to Share: Explaining the Conditions under Which States Delegate Governance
}

\author{
Aila M. Matanock \\ Stanford University, Political Science Department
}

September 2009

Center for Global Development 1800 Massachusetts Ave., NW Washington, DC 20036

202.416.4000

(f) 202.416 .4050

www.cgdev.org
I am extremely grateful to the Center for Global Development for funding this work, to Dennis de Tray and Vijaya Ramachandran for their support and assistance, and to Ibrahim Elbadawi and Todd Moss for reviewing the paper. The project would not have been possible without the guidance of Stephen Krasner. I would also like to thank Larry Diamond, David Lake, Michael Tomz, Jeremy Weinstein, Oliver Kaplan, Rachel Stein, Nora Bensahel, John Ciorciari, and participants in the Stanford International Relations Workshop and the Center on Democracy, Development, and the Rule of Law Research Seminar for comments and suggestions over the course of this project. Of course, however, responsibility for any mistakes, omissions, or other errors is my own.

This paper was made possible by financial support from the Australian Agency for International Development

Aila M. Matanock. 2009. "Learning to Share: Explaining the Conditions under Which States Delegate Governance." CGD Working Paper 181. Washington, D.C.: Center for Global Development. http://www.cgdev.org/content/publications/detail/1422780

The Center for Global Development is an independent, nonprofit policy research organization dedicated to reducing global poverty and inequality and to making globalization work for the poor. Use and dissemination of this Working Paper is encouraged; however, reproduced copies may not be used for commercial purposes. Further usage is permitted under the terms of the Creative Commons License.

The views expressed in this paper are those of the author and should not be attributed to the board of directors or funders of the Center for Global Development. 


\section{Foreword}

I am pleased to sponsor this working paper by Aila Matanock, a doctoral candidate at Stanford University, that explores the conditions under which states delegate some aspects of governance to an external actor. The paper is commissioned as part of CGD's ongoing work on weak and fragile states, which is focused on improving the effectiveness of post-conflict interventions. Matanock's paper contributes to this initiative by focusing on the role of external actors and the nature of their interaction with the host-country government. As the author notes in her abstract, this type of delegation occurs when there is a corruption or law-and-order problem. The paper contains new and interesting results about the circumstances under which these arrangements are self-sustaining. Given that we still do not have a good understanding of what types of interventions work and why, Matanock's findings are very useful. In particular, they will be of value to bilateral and multilateral institutions, which direct significant resources towards fragile states.

Vijaya Ramachandran

Senior Fellow

Center for Global Development 



\section{Learning to Share: Explaining the Conditions under Which States Delegate Governance}

Weak states now rival strong states as humanitarian and security concerns for the international community. Fragile or failing states not only neglect to provide needed goods and services to their own populations, but can also threaten other populations when they generate refugee flows, or when they are exploited by transnational human smugglers, drug dealers, money launderers, or terrorists. External actors, then, may have an interest in restoring effective governance to mitigate this risk, but not a consistently successful method for doing so. Invasion is increasingly recognized as problematic following experiences in Afghanistan and Iraq. State building after such a use of force, or from the outside, can lack the legitimacy and sustainability needed to achieve good governance (Chesterman et al. 2005). The alternative course of action for members of the international community is to work with the host state to rectify the weakness. A cooperative governance arrangement requires institutionalizing protection for the state's sovereignty, even if the government has lost the ability to carry out sovereign duties.

Delegation agreements emerge as possible solutions to this dual challenge of respecting international norms of statehood, while fulfilling the need for effective governance that the state cannot supply. They also address a fascinating theoretical puzzle in that they require shared authority: a host state legitimately relinquishes some of its power to another actor who takes responsibility for some governance function for a specific period of time. This paper explores cases in Melanesia that enact voluntary delegation to generate hypotheses about what they are apt to look like, and where they are initiated in this particular region. These case studies tentatively suggest that delegation agreements occur where a state faces an inability to govern caused by budgetary crisis due to corruption or extortion; however, violence, either in the form of a coup or at a level approaching civil war, will not initiate such an agreement because of the 
cost for the external actor. Additionally, the external actor must have a specific transnational concern about the state.

In the existing literature on intervention, there is a theoretical gap between host state control and external actor control, where arrangements including delegation agreements allow for shared responsibility for governance. In the work on state fragility or failure, theories that focus on aid effectiveness, recently including conditionality constraints, assume host state control of governance functions (Boone 1996; Burnside and Dollar 2000; Collier 1997; Svensson 2003; Girod 2007). Meanwhile, theories that focus on invasion or "neotrusteeship" assume external actor control (Paris 2004; Dobbins 2003; Dobbins et al. 2005; Hawk 2002; Ottaway 2002; Fukuyama 2004; Keohane 2003; Fearon and Laitin 2004; Helman and Ratner 1992). In between, there is the possibility for some form of shared governance between the host state and an external actor (Krasner 2004). The aim of this paper is not to explain all types of such sharing, ${ }^{1}$ but rather to specify a theoretically neglected mechanism used to address state fragility and failure, and to generate conditions under which it emerges. Thus, I focus on delegation agreements where an external actor is asked to help with some governance functions by the head of a sovereign state. This condition focuses analysis on the creation of self-enforcing equilibria in the anarchic realm of international relations. The arrangements generated, and the incentives motivating them, are a unique set.

I find that international treaties create such arrangements throughout Melanesia in two different forms: semi and strict delegations of governance. From these cases, I also generate hypotheses about the conditions under which states enter these delegating agreements. The political leaders in the host state and the external body make the decision to enter these agreements, so I focus on their incentives when I refer to either unitary actor. I suggest that the

\footnotetext{
${ }^{1}$ Many of which are defined in: (Lake 1999; Krasner 1999; Jackson 2007).
} 
host state requests this particular type of agreement where corruption, extortion, or violence force it to accept an external actor's terms of assistance in order to avoid losing office due to an inability to govern. Contrary to expectations, however, the last condition for these requests, violence, never actually generates an agreement since extensive on-going conflict, or even just a single significant ethnic cleavage in the society that might produce such conflict, make the external actor more likely to decline to help under these conditions. In addition to not wanting to face a costly intervention, and so only entering on a request not directly forced by violence, the external actor is also more likely to enter where the host state's weakness and proximity create a direct transnational security threat, and engage its international and domestic reputation. Thus, interested external actors are likely to engage in weak states struggling with a budgetary crisis brought on by corruption or extortion.

The article proceeds as follows. I first classify delegation agreements as the extension of government contracting into the international sphere, and I specify two types based on research in Melanesia, semi and strictly delegating. I show that these categories define two mechanisms for remedying state weakness in the region, and throughout the world. Next, I examine host state and then external actor incentives for implementing such arrangements. Finally, I discuss the limitations of the research, and suggest extensions for future study.

\section{Defining Delegation Agreements: Is Governance Delegated?}

What are delegation agreements? Generally, sharing governance functions "would involve the engagement of external actors in some of the domestic authority structures of the target state" (Krasner 2004, 108). Specifically, delegation agreements require the host state to relinquish some control, and an external actor to take on that responsibility, without complete subjugation 
of either entity to the other. Such agreements, then, are an extension of what is generally referred to as government contracting, where a government opts to outsource state functions to a contractor. However, international norms, politics, or law, rather than civil law, govern delegation agreements since these are an extension into the realm of international relations. Creating agreements in the international realm is particularly challenging since they must represent self-enforcing equilibria. There is no third party to coerce actors into maintaining a bargain given the anarchic nature of relations between states. However, international institutions, where states agree to cooperate through some degree of mutual behavior modification, are prevalent despite this difficulty (Goldstein et al. 2000). In the next section of this paper, I will differentiate between four types of relationships a host state might have with an external actor: advising, contracting, semi delegation, and strict delegation. I will then explain the conditions under which the latter two are likely, as self-enforcing equilibria.

Delegation agreements exist throughout Melanesia. I examine the independent Melanesian states because I knew there was some variation in the dependent variable to explain there: the Regional Assistance Mission to Solomon Islands is a canonical case of delegation. When I began the project, I was unaware of other such arrangements in the region, but I thought these states would be most similar to Solomon Islands in terms of environment, resources, culture, society, and politics, so as to narrow the potential independent variables. Once engaged in the research, I encountered several other cases of delegation that are not widely known outside the region, and both these cases and those of its absence were very useful in the initial work on the subject. ${ }^{2}$

\footnotetext{
${ }^{2}$ In researching this article, I conducted interviews with government officials, academics, and non-governmental organization workers in Australia, New Zealand, Solomon Islands, and Fiji during the summer of 2008. Many were willing to speak on record, so they are cited where applicable, and a full list of their names and titles appear in
} 
The independent Melanesian states include Papua New Guinea, Solomon Islands, Vanuatu, and Fiji. They range in population from a little over 200,000 in Vanuatu to almost six million in Papua New Guinea. All four countries gained independence between 1970 and 1980, and established their own democracies, which, although varied in the electoral rules, remain fairly open and freely contested as part of the Melanesian culture of continual competition for big man status (Hegarty 2008). General institutional weakness, however, led to faltering public goods provision and infrastructure, which hinders development, allows corruption of the systems that exist, and even occasionally leads to violence. The Pacific Islands Forum, a regional organization, and Australia both tried to assist these states through different arrangements over the past decades. These assistance agreements, especially as they progressed to intensive institutions within the last five years, are the subject of this analysis. The Melanesian cases may not be fully generalizable for a few reasons, including their small size and general weakness, as well as their highly interested neighbor, Australia. I discuss these possibly unique aspects further in the second section, and I suggest that the hypotheses generated here be rigorously tested in a broader sample that should overcome these potential limitations; however, based on initial research, it is plausible that similar agreements exist around the world, including cases in Cambodia, Chad, East Timor, Guatemala, Indonesia, Jamaica, Liberia, Mongolia, and Mozambique.

As this section shows, in Melanesia, delegation agreements in recent years vary markedly from previously employed external advising and contracting. Delegation agreements are enacted through international treaties that clearly identify the external actor as an independent entity given influence over the host's governance functions. I find two distinct levels of delegation:

Appendix 1. Some wished to remain anonymous, so I assign a number to each by which to cite them, along with the meeting's location and date. I thank all of those who facilitated and participated in the interviews. 
semi and strict. In strictly delegating agreements, the external actor is formally granted exemption from the rules or laws of the state, and then placed as an outsider into a position with direct responsibility for some aspect of host state governance. In semi delegating agreements, the external actor is similarly placed into a position with direct responsibility for some aspect of host state governance, but instead of being exempt from that state's rules or laws, it must work within them while maintaining its identity as, and allegiance to, a foreign government or multilateral organization. These agreements are usually bounded in scope and time, so that the host state maintains ultimate sovereignty. Over the course of this section, then, I use the Melanesian states to locate these delegation agreements in the spectrum of government contracting and classify them by how much authority they relinquish. In the final figures, I also specify where each major Melanesian state's governance agreements fall on the resulting scale.

\section{Non-Delegation}

Two arrangements that are important to distinguish from delegation agreements are advising/monitoring, and government contracting. These two devises were employed in Melanesia from independence until the present to strengthen the states. Advising and monitoring allow an external actor to suggest solutions to governance problems, but without the authority to execute these recommendations. Contracting assigns authority over some state function to an individual who does not have any dual allegiance, or special status, in that role. These represent important lower bounds on delegation: in both cases, the host state maintains exclusive authority over the governance function either because it makes the decision itself after hearing an advisor's suggestions, or because it assigns an individual governed by the state's laws without any special allegiance or status to make that decision on its behalf. Even in the realm of law and order, 
where the host state has a strong incentive to maintain complete control, advising/monitoring and contracting, as well as delegating are prevalent in Melanesia. Influence over the state's armed forces is particularly sensitive because of the power it represents, so external interference in this area is the most controversial. As they are the least likely area where we should see governance agreements, then, I primarily examine examples from this issue area as it makes a hard test.

In the region, external advising and monitoring armed forces has been commonplace, especially in the aftermath of conflict. An example is the International Peace Monitoring Team (IPMT) in Solomon Islands after the Townsville Peace Agreement (TPA). Despite the lack of a unified national identity or strong state structure (Dinnen 2002; Bennett 1987), Solomon Islands managed to maintain governmental integrity from independence in 1978 until the late 1990s. Honiara was established as the capital on Guadalcanal after World War II, and it quickly became the center of the national economy due to government and support infrastructure, as well as plantation and, more recently, mine development. Opportunity attracted emigration to the island, particularly from nearby Malaita, and ethnic identities deepened as a mechanism to compete for political resources (Dinnen 2002; Bates 1983). Meanwhile, despite adequate natural resources and donor aid to finance public goods, colonial institutions were not integrated with society's structure to effectively manage the state; because of this non-integration, an economic downturn caused by the Asian financial crisis led to conflict in 1998 (Bennett 2002; Moore 2005).

The conflict began in 1998, and did not end until the TPA was reached under Australian advice in 2000. In 1998, the Guales resubmitted a 1988 petition to Parliament that sought rent compensation for traditionally Guale land occupied by outsiders. Government reform under Prime Minister Bart Ulufa'alu, elected in 1997, made legitimacy more crucial to obtain resources that decreased with the Asian financial crisis. The petition, however, was denied, so Guales 
formed a militia, the Isatabu Freedom Movement (IFM) to rid the island of Malaitans (Moore 2005). In response, by 2000, Malaitans created the Eagle Force (MEF) which managed to co-opt much of the Solomon Islands police force (Dinnen 2002; Moore 2005). Australia denied requests for armed assistance by Ulufa'alu, but once he was forced out of office by the MEF in 2000, the state took a more active approach. Assembling the competing groups in Townsville, Australian negotiators helped them reach a peace agreement (Moore 2005). The, the TPA was monitored by the unarmed IPMT in 2000 . This group did not have capacity to actively police, but it did provide monitoring on groups' behaviors, and advice on how a lasting settlement might be achieved (Hegarty 2008). The Solomon Islands government thus did not delegate governance authority to IPMT, but, instead, constrained it to monitoring and advising role.

Contracting, similarly, entails submission to the host state. A law and order example from Melanesia is the police commissioner in Fiji. Fiji since its independence has been plagued by coups, usually the result of tensions between the Indo-Fijians and the indigenous Fijians. After each incident, accusations abound about who was involved. The 2000 coup was no different. Specifically, allegations of perpetration were made against the then police commissioner Isikia Savua ("Fiji Probe of Former Police Commissioner's Role in 2000 Coup Incomplete" 2003). He was removed as the head of police, while a panel investigated his actions. Due to these suspicions, a crucial concern in choosing his replacement was potential politicization of the police commissioner. Ultimately, the government decided that a foreigner would provide needed objectivity, so it requested a nomination from the Australian Federal Police (AFP) who recommended Andrew Hughes, a Canberra-based assistant commissioner ("Aussie to Head Fiji Police" 2003). Hughes resigned his position in the AFP to fill a limitedtime contract as an employee of the Fijian government. Ultimately, he quit after he and his 
family were threatened following another coup in 2006, and he reentered the AFP. During his stint in Fiji, however, he did not have dual allegiances ("Ousted Aussie Police Chief Returns To Ranks" 2006). Thus, this is an example of contracting from a government to a foreign individual under standard state law, where the individual does not wield any larger authority, or shoulder any dual allegiances of affiliation with an external actor.

\section{Strict Delegation}

In 2003, Australia's main strategy for assisting weak states in Melanesia contentiously shifted from advising to strict delegation, where the host state relinquished some authority over governance functions temporarily to the external actor. The host states solidified these arrangements by modifying the domestic legal apparatus to formally exempt the external actor from the host's normal law or procedure. In the cases in the region, modification of the domestic institutions involves either formally granting co-signing requirements to a body that is at least partially external for decisions regarding the funding and supply of public goods by distribution of the state's own funds, or allowing legal immunity for the external actor, not as a diplomat. This is the deepest delegation of authority possible by the host state without fully relinquishing its sovereignty.

The formative instance of a strictly delegated agreement is the Regional Assistance Mission to Solomon Islands (RAMSI) which was signed in 2003. The TPA, discussed above, did not restore lasting law and order (Hegarty 2008). Inter-ethnic conflict gave way to intraethnic and more general conflict, as the militias turned on the government, sometimes in an alliance with particular politicians, to extort all of the treasury's funds; after 2000, these funds primarily included the aid that Taiwan supplied annually in exchange for recognition (Fraenkel 
2008). Finally, in 2003, Prime Minister Allan Kemakeza requested assistance from the Australian government that resulted in an extensive regional assistance mission.

Under this agreement, an Australia-led Pacific Islands Forum deployment of more than 2,000 troops and other personnel was dispatched to Solomon Islands to reestablish the rule of law, and then effective governance more generally. The program requires annual review, and contains the option of terminating the agreement in three months, by a majority in parliament. Aside from these criteria for exit, however, the arrangement is fairly demanding: it grants substantial authority to RAMSI personnel, as well as some legal immunity. The treaty between Solomon Islands and the participating states led by Australia suggests that the external actor's role is to:

Assist in the provision of security and safety to persons and property; maintain supplies and services essential to the life of the Solomon Islands community; prevent and suppress violence, intimidation and crime; support and develop Solomon Islands institutions; and generally to assist in the maintenance of law and order in Solomon Islands ("Agreement between Solomon Islands, Australia, New Zealand, Fiji, Papua New Guinea, Samoa and Tonga" 2003)

In order to carry out these broad tasks, members of the regional mission not only filled in-line rather than advisory positions, but were specifically allowed to operate without Solomon Islands oversight: the head of RAMSI has exclusive "internal command, control, discipline and administration" over its members ("Agreement between Solomon Islands, Australia, New Zealand, Fiji, Papua New Guinea, Samoa and Tonga" 2003). The Participating Police Force, PPF, is explicitly exempt from being subject to the orders of any of its counterparts, although its head, the Deputy Commissioner of the Solomon Islands Police Force, should "consult" with the Commissioner of the Solomon Islands Police Force who is appointed by the Solomon Islands government ("Agreement between Solomon Islands, Australia, New Zealand, Fiji, Papua New Guinea, Samoa and Tonga" 2003). This technical ranking of the indigenous police head above 
that of the external police head was meant to help the agreement fit the conception of sovereignty embodied in the constitution, but, not only is the chain of command not legally binding, the commissioner has been a Brit, Aussie, Fijian, and New Zealander since RAMSI was enacted, with two of these individuals actually on the mission's payroll (Confidential \#5 2008; Afeau 2008).

In addition to the roles and responsibilities assigned the mission, the agreement is particularly deep due to the legal immunity extended to its members through an act unanimously approved by the Solomon Islands parliament (Solomon 2003). While Australia originally pushed for blanket immunity, the compromise insulates personnel from on-the-job civil and criminal charges, and also offers the home country first right to prosecute in other cases (Campbell 2008; Afeau 2008). This agreement, then, demonstrates delegation of broad areas of discretion to the external actor to pursue broader aims for the host country, as well as special exemptions for the personnel bound to implement the treaty that are solidified in through a domestic legal apparatus.

\section{Semi Delegation}

Once RAMSI enacted strict delegation, compromise agreements in other Melanesian states also generated a slightly less rigorous form, semi delegation. In these cases, members of the intervention work for the host government, but maintain a dual role as external actor; thus, the host state and external actor must negotiate the conditions of this international cooperative agreement, so it is fundamentally different than government contracting. Rendered through a political treaty, these positions require individuals to pursue the aims of both host and external actor simultaneously. In practice, in the region, this is generally through the placement of the 
external actor's own personnel into in-line positions in the host state's infrastructure, while they are paid and receive some orders by their own state.

A case of semi delegation is Papua New Guinea beginning in 2005 under what came to be known as Strongim Gavman Program (SGP). After the early success of RAMSI in Solomon Islands in 2003, Australia proposed a similar, although unilateral, whole-of-government agreement for Papua New Guinea. The two states discussed an Enhanced Cooperation Program (ECP) in December of that year, to address issues of "governance, law and order and justice, financial management, economic and social progress as well as capacity in public administration" ("Joint Agreement on Enhanced Cooperation Between Australia and Papua New Guinea" 2004). The original treaty pledged limited legal immunity to Australian members of the mission, and the supporting legislation passed in the summer of 2004 (Dinnen et al. 2006). Under the ECP, then, similar to RAMSI, a strict delegation agreement was set to come into effect where over two hundred police and about sixty other Australian officials would be placed primarily in in-line positions in Papua New Guinea (Fukuyama 2007b).

The strategic environment in Papua New Guinea, however, was far different from that of Solomon Islands. The country faced high rates of urban crime and largely ethnic conflict in rural areas, including the Highlands and Bourgainville, as well as wide-spread corruption, slow development, and an increasingly worrisome public health situation especially with regard to HIV/AIDS (Dinnen 2000; Passey 1996). These problems were monumental, but the state continued to carry out some of its functions at a basic level, as opposed to the pre-RAMSI Solomon Islands where that became impossible: Port Moresby did not find itself in the midst of a state-wide conflict, nor did this conflict completely debilitate the government. 
Thus, Papua New Guinea resisted ECP from the beginning, and especially in that it suggested that the state had failed, so Australia pushed the agreement onto the state unilaterally, which is discussed further in the next section (Dinnen et al. 2006). Successful opposition to the mission finally came from a Supreme Court challenge to ECP filed by Luther Winge, governor of Morobe Province, who claimed that the immunity granted was unconstitutional, which overturned the special privilege granted to the mission in 2005 ("Wenge to Test ECP's Validity in Court" 2004; "Focus-ECP's Legal Fallout on Immunity" 2005). At this point, the police forces and many officials withdrew, but some in-line administrators remained, including in the prosecutor's office, and effected policy in these government agencies as dual members of the external and host states (Confidential \#10 \& 11 2008). Thus, post-2005, the bilateral agreement that became known as the SGP between Australia and Papua New Guinea represents a semi delegating agreement.

While the Melanesian examples I use to categorize the potential mechanisms for affecting governance capabilities primarily regard the armed forces, they bleed into other issue areas. Indeed, while law and order agreements are the most controversial, and thus the most likely to be debated and formalized, similar arrangements exist on other governance responsibilities. The Sustainable Development Program (SDP) over the Ok Tedi Mine is one such example of strict delegation that does not involve law and order. In this case, BHP Billiton opened a copper mine in Papua New Guinea's Western Province without sufficient health or environmental safeguards. After some court wrangling, the company was allowed to forsake corporate responsibility for these omissions, provided it helped continue the operation of the mine and distribute its profits to rectify the damage done. To do this, the company formed a group, the PNG Sustainable Development Program Limited, to receive the after-tax profits from the mine, invest them in 
Singapore, and then distribute them over time to development programs in the Western Province. The corporation is composed of three Papua New Guinea nominees and three BHP Billiton nominees, as well as one Singaporean elected by the members. The mixed nationality of the board, and the fund's placement offshore was meant to ensure that the money would "lead to responsible governance of the large asset that [the mining company] was transferring to support development in Papua New Guinea" (PNG Sustainable Development Program Limited ), rather than being "diverted to potentially corrupt uses" (Fukuyama 2007b). The Mining (Ok Tedi Mine Continuation (Ninth Supplemental) Agreement) Act passed by Papua New Guinea's legislature in 2001 solidified this arrangement. This, then, is an external mechanism for distributing government funds that is mandated through a legal mechanism in the host country. The issues covered by the project are largely environmental, along with some public health assistance.

FIGURE 1: Defining Gowernance Arrangements

\begin{tabular}{|c|c|}
\hline Strictly Delegating & $\begin{array}{l}\text { FAIMSI } \\
\text { ECP } \\
\text { SDP }\end{array}$ \\
\hline Senti Delegating & $\begin{array}{l}\text { MOU } \\
\text { SGP } \\
\text { TGUs }\end{array}$ \\
\hline Contracting & $\begin{array}{l}\text { Satidline Intemational } \\
\text { Hughes }\end{array}$ \\
\hline $\begin{array}{l}\text { Motnitoritig/ } \\
\text { Advising }\end{array}$ & $\begin{array}{l}\text { TMG } \\
\text { IFMI }\end{array}$ \\
\hline
\end{tabular}

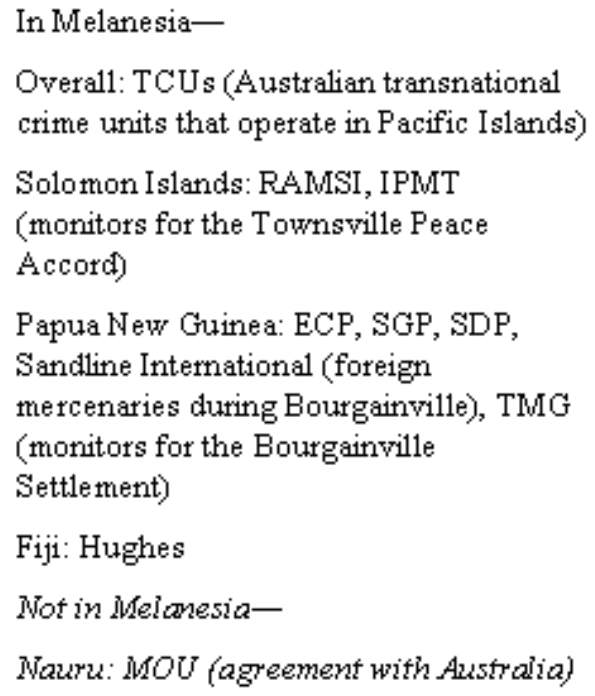


Overall, then, a few crucial components identify delegation arrangements: the deal must be enacted through a treaty, rather than a contract, so that the external actor maintains some autonomy while performing a governance function for an independent host. The difference between strict and semi delegation is whether the external actor is given full authority by the host, or if it instead maintains dual allegiance. These agreements are of particular interest since they are where we can examine the incentives for constructing self-enforcing arrangements, rather than contacts that are merely under the jurisdiction of national law. Specifying this spectrum, and demonstrating its existence through case study in Melanesia (please see Figure 1), then, is the prelude to the question explored here: why do states agree to delegate in this way?

\section{Enacting Delegation Agreements: Why Share Governance?}

Shared sovereignty agreements, then, are a fundamentally unique and coherent set of cases where actors locate self-enforcing equilibria under the anarchy of the international system. Since these deals are by definition made by independent entities, there must be conditions under which both the host state and the external actor prefer the agreement to the alternatives available. The Melanesian cases in the previous section indicate that such conditions are at times a reality. What, then, are the conditions are under which actors enter delegation agreements? Why would a host state willingly constrain its power? And, why would an external actor agree to accept some responsibility, including the associated costs, for this state?

Comparative case study on Melanesia identifies conditions under which delegation agreements emerge in this region. Specifically, these states' experiences suggest that a host will request such assistance either where it lost its monopoly on the use of force, or where it faces a severe budgetary crisis. Violent conflict, or even a single major ethnic cleavage in a society, 
however, may prevent such agreements from coming to fruition. In such cases, the external actor will refuse this type of assistance since it is only interested in these arrangements where they are likely to be cost-effective mechanisms for mitigating transnational security concerns, while addressing international and domestic reputational effects. So, based on induction from these cases, we find delegation agreements where a state faces an inability govern caused by budgetary crisis due to specifically to corruption or extortion, and where an external actor has specific transnational concerns about that state.

This section proceeds in two parts: one on the host state incentives, and one on the external actor incentives. Each component briefly reviews existing literature, but shows that it offers few explanations of the decision to enact shared sovereignty agreements from the perspective of either the host or the external actor. The Melanesian cases, then, provide an initial probe of the limited hypotheses found in the current work on the topic, and add alternatives. Based on these studies, each sub-section generalizes the conditions under which delegation agreements may emerge, based on the incentives they offer each actor, and also addresses the potential generalizability of these cases.

\section{Host State Incentives}

The existing literature rarely proposes incentives for the host state to enter a delegation agreement, which is likely because many conceive of situations of sharing sovereignty as emerging from war, where there is no independent state to decide on the arrangement (Dobbins 2003; Dobbins et al. 2005; Dobbins et al. 2008; Paris 2004). Explanations of host incentives are generally limited to privatization arguments about government contracting, which do not fit the definition laid out in the previous session, since delegation agreements involve granting authority 
to an external actor with special privilege (Feigenbaum and Henig 1994; Kaplan 2006). The exception to this lapse is Stephen Krasner's work, which suggests that there are four possible motivations for states to enter delegation agreements: desperation due to bad governance or civil war, avarice over natural resources, election incentives, or post-conflict occupation (Krasner 2004). Krasner does not, however, specify these conditions, or offer evidence that they lead to delegation agreements. Additionally, this analysis rules out post-conflict occupation since, at least initially, there would be no independent host decision to delegate. In assessing the other hypotheses in the context of the Melanesian cases, especially RAMSI since it is a lasting case of delegation, I find that desperation is the most likely to generate requests for delegation, and particularly desperation regarding civil conflict, especially lawlessness, or budgetary crisis.

Turning first to desperation over bad governance or conflict, we must define this into useful indicators to suggest when a delegation agreement is likely. State weakness and failure are often merely defined as political crisis or violence (Esty et al. 1998), or "as the extreme end of a continuum of the weakening of state governing capacity that it would be unhelpful to analyze separately" (Milliken and Krause 2002). Collapse, in particular, seems to be so treated: the State Failure Task Force identifies it as revolutionary war, ethnic war, "adverse regime change," or genocide (Goldstone et al. 2000b). Some, however, suggest that failure is "a deeper phenomenon than mere rebellion, coup, or riot. It refers to a situation where the structure, authority (legitimate power), law, and political order have fallen apart and must be reconstituted in some form, old or new" (Zartman 1995). Drawing on a wide segment of the literature on state weakness and failure, then, Jennifer Milliken and Keith Krause suggest three core functions for the state, and, thus, areas in which we might see dysfunction: providing security, welfare, and representation to its people on other issues (Milliken and Krause 2002). Components of the 
more traditional forms of failure in terms of law and order problems fall into the first category, to which we now turn.

Security weakness or failure is frequently highlighted as particularly devastating in the literature on state dysfunction, and, indeed, as a motivation for turning to an external actor in Melanesia. In theory, states can fail in a variety of ways with respect to security: most fundamentally, they can fail to secure law and order through failure of the chain of command, which may lead to a coup, or through erosion of the monopoly on force, which may lead to civil war, widespread crime, or extortion (Krause 1996; Reno 1999; Krasner 2004; Milliken and Krause 2002). Security deficiencies may be the reason for the requests for aid from different Melanesian states, especially Solomon Islands. Indeed, an inability to restore a monopoly on force is likely a motivator in that case, and, perhaps, in Papua New Guinea to a lesser extent. In Solomon Islands, a failure to secure law and order certainly seems to be a relatively important component of the decision to request external aid. Bart Ulufa'alu was the first of a series of prime ministers to request massive assistance for the state. During his term between 1997 and 2000, he tried to reduce illegal governance and solidify institutions (O'Callaghan 2000; Garran and O'Callaghan 2000; Moore 2005), but he was met resistance, as the economy slowed and Guales re-petitioned for compensation from the shrinking economy based on their traditional land claims (Moore 2005). When their request was denied, and fighting broke out, Ulufa'alu declared a state of emergency in 1999 (Dinnen 2002). By 2000, a militia group had taken over command of a significant portion of the police force (Dinnen 2002; Moore 2005). In this moment, the government recognized that it had lost all monopoly on the use of force, and requested police assistance from Australia (Nolan 2008; Moore 2005). After militants forced Ulufa'alu's resignation by kidnapping, they supported Sogavare's bid for office (Downer 2008). 
Soon, however, he also allegedly sought external assistance (Kabutaulaka 2008). Finally, his successor Allan Kemakeza appealed successfully to the Australians, after likely meeting with a few other potential interveners (Cook 2008; Moore 2005). Kemakeza had relied heavily on the Malaitan militants for his security, but it was a delicate balancing act that likely ended because several of his cabinet members resigned after threats on them and their families, and he himself may have even faced a similar threat after failing to meet demands of the MEF (Hayward-Jones 2008; Moore 2005). At this point, former Australian Foreign Minister Alexander Downer claimed, "Unless we did something, the place would collapse [due to a law and order problem]" (Downer 2008). RAMSI, then, focused initially on restoring law and order (Warner 2008; McDevitt 2008).

In regional perspective, however, breakdown of law and order does not appear to be a necessary or sufficient condition for requesting a delegation agreement. By standard definitions, there has been only one civil war in the region during the period since independence, when Bourgainville attempted to break away from Papua New Guinea between 1988 and 1998 (Fearon and Laitin 2003), which was not accompanied by a request to delegate a governance function to an external actor. There are three of what the State Failure Task Force calls adverse regime changes in Melanesia, which are "major, abrupt shifts in patterns of governance, including state collapse, periods of severe regime instability, and shifts toward authoritarian rule" (Goldstone et al. 2000a). One of these is the 2000 moment in Solomon Islands discussed above, but the other two are coups in Fiji in 1987 and 2006. Fijian Prime Minister Qasare may have requested police assistance before the 2006 coup (Chand 2008); although he denied doing so after his government fell, he was tried for treason for it (Downer 2008). Coups, then, may cause delegation requests, but they are not a consistent cause of shared sovereignty requests, or their enactment. 
Interestingly, even in the cases where they led to requests, the external actor was not receptive. I will return to this in the next section.

Initially, the breakdown of law and order in Solomon Islands resulted in the forced resignation of a prime minister due to kidnapping, which brought initial pleas for external assistance; however, by the time a delegation agreement was actually considered and then enacted in 2003, it was really widespread crime and extortion that plagued the islands, rather than a motivated military on a political mission, as in Fiji (Hegarty 2008; Chand 2008; Wainwright 2003). Although they are not identical, both Solomon Islands and Papua New Guinea did share this kind of disorder. The problems in Solomon Islands were not the same as in Papua New Guinea, as the former displayed a "more African" quality with potential "urban gangs and warlord armies," whereas in the latter "it is very hard to imagine a Charles Taylor emerging” (Fukuyama 2008, 2007a). In Papua New Guinea, security was a symptom of a broader problem of increasing administrative deficiencies generally (White 2008; Chand 2008). Thus, Papua New Guinea, like Solomon Islands, had a much higher crime rate than the rest of Melanesia prior to the invitation of ECP: 9.1 average annual homicides per 100,000 people compared to 1.7 for Fiji and 0.07 for Vanuatu between 2000-2004 ("Human Development Report" 2007/2008); however, levels of violence in both countries were much higher, and closer to civil wars, in the years prior to delegation agreements. As Kemakeza's involvement with the MEF indicates, politicians may have an optimal level of political disorder in their own society where they can profit in money or favor, but when extortion makes governance impossible, they may seek external assistance. Over time data on specific criminal activity is not available to indicate if a decrease in law and order led directly to the assistance appeals, but anecdotal 
evidence suggests increasing levels of extortion led to an inability to rule, which was an important factor (Hegarty 2008; Chand 2008; Wainwright 2003).

A host state may also delegate because of economic weakness or failure, which may or may not be directly tied to a security issue. Anecdotally, economic failure is cited as the culprit in causing the conditions that necessitated external help in Solomon Islands and Papua New Guinea. Solomon Islanders suggest that financial collapse, perhaps due to the Asian crisis in combination with their "own version of Dutch Disease," was compounded by poor economic leadership, including corruption, as the impetus for the requests to the Australians (Kenilorea 2008; Wickham and Roughan 2008). In Papua New Guinea, stagnation is cited as a cause of the intervention (Downer 2008), perhaps due to some similar form of administrative and development failure, which may also have involved reliance on one type of export, minerals (Chand and Levantis 2000). More generally, welfare falters where contract enforcement deteriorates, which might be apparent through lower levels of investment, where trade decreases (Goldstone et al. 2000b; King and Zeng 2001), or where GDP or GDP per capita is stagnant or declining (Krasner 2004; Milliken and Krause 2002). While most of these factors may be difficult to link directly to requests for assistance, rather than as causes of security failures, governmental budgetary crises appear to be a decisive factor in the South Pacific. Corruption is a possible contributing factor to weakness or failure, but this also is highly tied to lawlessness (Krasner 2004).

Many measures of welfare failure are difficult to find in the region, and then even more challenging to separate from law and order concerns, and either may drive delegation requests. For example, foreign direct investment fell in each Melanesian state between 1990 and 2005, but its decline may have been due to political turbulence in some of these countries, and, indeed, it 
remained positive only in Papua New Guinea and Vanuatu, which did not experience coups ("Human Development Report" 2007/2008). Similarly, the trade deficit in Solomon Islands, as reported by its national statistics office, worsened in the years leading up to RAMSI, but actually improved just before the request. Missing data around the conflict, however, makes confidence in this pattern difficult to gauge. GDP also dropped drastically during the crises, and during the requests for assistance in both Solomon Islands and Papua New Guinea; such drops are, however, also present in other states that do not make a request, like Vanuatu in the 1980s (Stewart 2006). Per capita GDP shows more of a steady decline at an already low level in the states that request aid, while in Fiji, for example, UN and Asian Development Bank reports indicate that the standard of living is relatively high (Firth 2008). Economic concerns both lead to and are produced by conflict, so it is difficult to separate the specific initial impetus for the request, but generally it is thought to be the latter in Solomon Islands (Bensahel 2008; Fraenkel 2008). These indicators, then, may be a factor in initiating requests for delegation agreements, or they may just contribute to a general weakness or failure.

State budgetary crisis, however, is a plausible cause of such requests, either in conjunction with conflict, or not. A state in the region, but not the Melanesian sample, Nauru, suggests that lack of government funds can be a crucial aspect in the decision to request an external actor's assistance, even absent a law and order problem. Although a state with an initially high GDP per capita for the region, Nauru faltered in the 1990s due to poor financial management, and eventually faced a severe budgetary crisis (Fry and Kabutaulaka 2008b). In 2001, before the national election, former Australian Prime Minister John Howard negotiated the "Pacific solution" with former Nauruan Prime Minister Rene Harris, whereby the host provided a processing center for asylum-seekers apprehended by the Australian Navy in return for massive 
economic aid (Fry and Kabutaulaka 2008b). By 2003, however, the financial situation had not improved, which led to several proposals for Nauru: Australian citizenship, resettlement, or Australian control over crucial governance functions to improve the state (Forbes 2003; "Leaving Nauru Not an Option: President" 2003). Nauru accepted the third option, and delegated control over financial management and policing, as well as education and health, to Australia in May 2004 ("Agreement Between Australia and Nauru Concerning Additional Police and Other Assistance to Nauru" 2004). In mid-2004, the Nauru government also turned to the Pacific Island Forum under the Biketawa Agreement for the Pacific Regional Assistance to Nauru, PRAN (Fry and Kabutaulaka 2008b). In this case, budgetary crisis, and, thus, desperation, of the host forced it to allow the external actor to set the standards of the agreement, which involved significant intervention (Downer 2008).

Similarly, in Papua New Guinea, the treasury led the request for assistance when it could not generate sufficient funds to cover the budget (Chand 2008). The structure of ECP was likewise imposed on the country (Downer 2008; Confidential \#5 2008). Australia, then, offered the aid as a component of a delegation agreement it desired.

The case is murkier where both conflict and economic crisis coexist. In Solomon Islands, "the government could not enforce law and order. Corruption and extortion drained government resources and service provision faltered. Domestic production was collapsing and the economy's spiraling debt was becoming unmanageable" (Dobell 2008). Australian officials may have also instigated it by suggesting that they would provide assistance, but only if it came in a whole-of-government package (Austin 2008; Dinnen 2008). The evidence for this, however, is not completely convincing. These other cases, though, certainly suggest that merely gaining access to aid, especially under conditions of severe budgetary crisis, may motivate governments 
to accept considerable restrictions on their power. Former Australian Foreign Minister Alexander Downer suggested that the external actor drives these arrangements by stating that potential hosts "don't have to take our aid, and we don't have to interfere with their sovereignty" (Downer 2008). It is not clear from Melanesia if external actors always drive this type of agreements, but it appears to be the case in Papua New Guinea.

Where budgetary crisis could be the motivating factor, corruption is a possible mechanism that drives states to this point, and that makes a delegation agreement more desirable than the alternatives. Corruption, accompanied in some cases by extortion, is often cited as a massive problem in Melanesia. Data on corruption in the region is extremely difficult to find: Transparency International (2006), for example, only ranks Fiji and Papua New Guinea in their global report, but it suggests that the latter is failing massively ( $130^{\text {th }}$ out of 206 countries $)$ compared to the former $\left(55^{\text {th }}\right)$. A lack of more specific information makes investigation of a causal theory very difficult. Under this theory corruption itself is not the cause of a request as politicians may benefit from some level of it; it is only when it drives a budgetary crisis that they seem concerned. Allegations that corruption, along with extortion, increased in Solomon Islands, Papua New Guinea, and Nauru to such an extent that it drove the treasuries into crisis is possible, but difficult to ascertain. If it is true, though, solving this particular problem is most feasible with external oversight. Thus, severe budgetary crisis, likely driven by extortion related to lawlessness or corruption, may be a cause of host state requests for delegating agreements. Other economic indicators, like investment and trade, are difficult to separate over time from other possible reasons of general failure, so they are not as directly implicated as motivators here. 
Instead of either security or economic difficulties, representation issues could lead to a request for delegation. The Melanesian cases, however, suggest that quality of representation does not account for the difference, but that overall fractionalization of identities may contribute. The State Failure Task Force lists the character of the political institutions, measured as regime type, as well as ethnic or religious composition of the population or leadership, as causes in the breakdown of the state (Goldstone et al. 2000b; King and Zeng 2001). The Polity II scores, however, suggest that there is not a consistent character of political institutions when hosts request delegation; they vary in the Melanesian cases, but do not follow a particular pattern in their levels or trends prior to a request. An interesting sub-hypothesis that emerges here, though, is that an ethnically fractured state may actually be more likely to successfully appeal than a state with one major cleavage. Benjamin Reilly has suggested that Papua New Guinea may be able to sustain its strong democratic character because it is so fractionalized that no single conflict overtakes the system (Reilly 2001; Reilly and Wainwright 2005). Interestingly, the most fractionalized countries, Papua New Guinea - which is almost perfectly fractionalized according to Fearon's measure — and Solomon Islands, have delegation agreements, while those with one strong cleavage, Indo-Fijian versus Fijian in Fiji and anglophone versus francophone in Vanuatu, do not (Fearon 2002; Barrett et al. 2001). Some have suggested that a plan for delegation may provide a focal point in divided societies where collective action is very difficult (Liloqila 2008; Reilly 2008; White 2008). One strong ethnic cleavage into two distinct groups, as in Fiji, then, may be more conflicted about which population such an agreement would help (Chand 2008), and thus one side might be more likely to effectively oppose an agreement. Thus, not only could a request be less likely, but, especially, the external actor may be unwilling to engage due to the potential cost, as will be discussed in the subsequent section. The cost, and 
thus the unwillingness, however, may be shaped by the strength of the different groups created by the cleavage, and by which one requests the assistance.

I find little support for other hypotheses as to the host state's motivations in requesting a delegation agreement. Krasner suggests that avarice over natural resources may cause requests, but there are few deals enacted over these resources in Melanesia, despite the prevalence of oil, gas, gold, copper, and other minerals. The only case in which a delegation agreement has led directly to greater funding from a natural resource is the SDP over the Ok Tedi copper mine in Papua New Guinea. In this case, though, there is no central receipt of any more government money in the delegation arrangement than there would be if the mine were operated merely by contract, as the funding goes directly into environmental and public health in the Western Province, rather than finding its way to the capital (PNG Sustainable Development Program Limited ). This may act as pork then to the few politicians from the region, but, more importantly, perhaps, the agreement ensures that the mine continues to operate, which generates taxes since it was too politically risky and potentially costly for a mining company to run for regular profit (PNG Sustainable Development Program Limited ). As far as I know, these funds are not distributed to a potential rebel group, either, who might otherwise turn on the government. Rather than greed over natural resources, then, this story suggests a need for general government income. This, then, matches the case for budgetary crisis driving delegation agreements, as discussed previously.

Another of Krasner's suggestions based on logical possibility, political incentives, also seems unlikely here. Considering the massive pressure faced by the prime ministers who have implemented delegation agreements in Melanesia, it is less apparent that they considered their political survival at election time, rather than much more immediate risks of assassination, coup, 
or parliamentary vote of no confidence (Hayward-Jones 2008). In Solomon Islands, "the most remarkable thing about the [Kemakeza] government was that it survived" both physically and politically (Moore 2005). RAMSI did have massive political support, ${ }^{3}$ although perhaps not quite as much as the mission claims based on its own polls (Allen 2006), but it was unlikely that gaining the popularity associated with it was what was needed to maintain position as prime minister: not only does Solomon Islands have extensive patronage political systems in place, but also the prime minister is elected through a separate, opaque process that relies on his ties to other politicians more than anything else (Hayward-Jones 2008). Facing grave threat, it is unclear that Kemakeza was able to strike a good deal for those himself in terms of ensuring he had funds to pay his supporters or in terms of protecting his allies (Liloqila 2008). Kemakeza did muster unanimous support for RAMSI, but ultimately at a cost to him, as several of his cabinet members were arrested and he himself is even now serving jail time for misappropriating government funds (Warner 2008). An additional mark against elections as a motivating factor is that it is unclear that the ECP was popular in Papua New Guinea when it was initiated (Scott 2005; Vulum 2005).

Overall, in the Melanesian cases, host states seem to have two motivations for delegating some governance to an external actor: either a failure of law and order that requires assistance to re-secure the monopoly on force, or a budgetary crisis that requires assistance to provide state funds. In this section, we also have some hints that initiating a delegation agreement may be quite costly during active fighting, or where there is a main cleavage in a society, so then opposition to such an arrangement is likely. These factors will be discussed further in the next

\footnotetext{
${ }^{3}$ The Solomon Islands Development Trust, a domestic NGO with deep community roots, ran a survey three weeks before RAMSI and found 94\% approval for the impending intervention. By February of the following year, 2004, $88 \%$ were behind at least the law and order component. Also in 2004, the Pacific Island Forum widely interviewed Solomon Islanders to assess RAMSI, and found massive support for it. RAMSI itself also runs annual surveys that show high levels of support for the mission (Anderson 2008).
} 
section. Ultimately, then, extortion, related to lawlessness, or corruption that leads to a budgetary crisis generates a delegation agreement in these cases; a major violent conflict or coup in a divided society instead sometimes produces a fruitless host request. Finally, I do not find much support for other hypotheses suggested in the literature on host state incentives, like avarice over natural resources or electoral incentives. These findings are summarized in Table 1.

TABLE 1: Summary of Hypotheses and Findings on Host State Incentives

\begin{tabular}{|c|c|c|}
\hline Literature Hypothesis & Modifications & Cases of Support \\
\hline \multicolumn{3}{|c|}{ 1. Desperation Over Civil War or Bad Governance } \\
\hline & la Security & \\
\hline & Coup, or Large Civil Conflict & Can lead to request, but no agreement (Fiji, Solomons) \\
\hline & $\begin{array}{l}\text { Extortion Due to Loss of Control } \\
\text { Over Law and Order }\end{array}$ & RAMSI, ECP (negative support from Fiji) \\
\hline & 1b. Welfare & \\
\hline & General Economic Issues & Unclear, but unlikely outside of conflict \\
\hline & $\begin{array}{l}\text { Budgetary Crisis, Likely Due to } \\
\text { Corruption or Extortion (la) }\end{array}$ & ECP, MOU, maybe RAMSI \\
\hline & 1c. Representation & \\
\hline & Struggle for Representation & Unlikely \\
\hline & Fragmented, Not Cleaved, Society & RAMSI, ECP (negative support from Vanuatu and Fiji) \\
\hline 2. Avarice Over Natural Resources & & Unlikely, but maybe SDP \\
\hline 3. Election Incentives & & Unlikely \\
\hline 4. Post-Conflict Occupation & & Ruled Out By Definition \\
\hline
\end{tabular}

Are the Melanesian cases representative of states that might request shared sovereignty agreements internationally? It is possible that the Pacific states may not be able to exert internal sovereignty on their own, as some of them are small and devoid of resources, including land; this is unlikely to be a concern about Papua New Guinea or Fiji, but may apply to Solomon Islands or Vanuatu (Firth 2008; Cook 2008). Additionally, these states may suffer from internal weakness perhaps due to their recent peaceful shift to independence. Cristoph Zuercher argues that different types of governments, in different levels of capability collapse, will have different preferences for the components of the state under their control (Zuercher 2006), so some of these states may be much more willing to enter extensive agreements than the average state. However, many developing countries, especially African states, are conceived of as these "quasi-states" (Jackson 2007; Herbst 2000). Rather than offer a firm answer to these concerns about how 
representative these states are, I offer the hypotheses that these cases generate as potentially applicable to other quasi-states, and possibly applicable to other developing states, but acknowledge that they should be tested across other cases in further work on the subject before any more solid theory emerges.

\section{External Actor Incentives}

I now turn from the host state's incentives in delegating some governance responsibilities to the external actor's incentives in possessing those responsibilities, which are also infrequently discussed in the literature. Most of the research on external actors intervening in host states focuses on the success or failure of the endeavors, and much of it only addresses cases where the intervention arrived by force to resolve an inter-state or intra-state war (Paris 2004; Dobbins 2003; Dobbins et al. 2005; Hawk 2002; Ottaway 2002; Fukuyama 2004; Keohane 2003). There are some suggestions, though, that devolution of sovereignty may remedy problems of governance less than war, especially in terms of state failure (Krasner 2004; Fearon and Laitin 2004; Krasner 1999; Jackson 2007). Most of these articles propose that an external actor should be motivated to enter into such agreements to remove transnational threats that come with state weakness and collapse, but that actually doing so is rare, either because no single actor is so threatened that it has incentive to take the responsibility unilaterally (Fearon and Laitin 2004), or because of the lack of options in dealing with such situations (Krasner 2004). The first section of this paper, however, indicates that a particular type of these agreements, delegation, is frequently enacted in Melanesia, so under what conditions does an external actor actually involve itself?

In the South Pacific, Australia is perhaps more likely to intervene than major actors in other regions, but there is still a difficult question of when delegation agreements will occur. 
Australian policy-makers view themselves as the closest state capable of such endeavors, and the one that will suffer most if various weakness and failure scenarios occur, so the state has some direct interest in the fate of its neighbors (Wainwright 2003). There are thus potential issues with the generalizability of the external actor in the Melanesian cases since Australia might be much more interested in the region than anyone is where other requests emerge; however, locating the cause of this interest may still generate hypothesis that apply to external actors in other regions, although they might be bounded by restrictions that emerge from the exceptional aspects of this case. Additionally, even in Melanesia, these motivations are not easy to locate: Australia had a policy of aiding but not interfering with its neighbors until 2003. Indeed, in January of that year, Former Foreign Minister Alexander Downer said, "Sending in Australian troops to occupy Solomon Islands would be folly in the extreme," yet by the summer Australia had done just that (Cited in Fullilove 2006). What changed the incentives for this external actor?

In this section, I locate and assess the explanations supplied for Australian engagement, through the Pacific Islands Forum, PIF, in Solomon Islands. I bring in what evidence exists from other cases, but focus on RAMSI because it is one of the earliest, longest, and most discussed agreements of its kind in the region. I find that transnational security concerns are an important initial motivator, but that they will only drive agreements where they are not too costly in terms of the difficulty of engaging, and where they improve that actor's international and domestic reputation.

Economic interests, humanitarian concerns, and larger strategic considerations are often suggested as potential causes of intervention, but they prove unconvincing in the RAMSI case. Economic concerns, relative to Australia's GDP, were small. Exports to Solomon Islands dropped about \$36 million (Australian), while imports fell \$2.6 million from 1997 to 2002 
(O'Connor 2003). Compared to the Australian GDP, which was about $\$ 400$ billion in 2002, these are not major stakes. Australian companies invested in both the timber and gold industries, but these operations, too, were tiny: Gold Ridge, for example, the main goldmine produced just 210,000 ounces between its opening in 1998 and the conflict (Australian Solomons Gold Limited). Some suggest that, though these interests were minor, they were quite vocal (White 2008). There is little evidence, however, to show that they had much sway with politicians, and, indeed, despite the current stability, Gold Ridge, for example, has not even reopened yet (Downer 2008; Fraenkel 2004).

Humanitarian concern is also an unlikely explanation for Australia's decision to lead and fund the PIF mission to Solomon Islands. The public probably did not generate such an urge, as policy-makers were unaware of any real widespread interest about the case in Australia (Downer 2008), and research on the United States often suggests that elites drive mass foreign policy considerations, anyway (Zaller 1994). If elites were concerned, on the other hand, this might be a feasible intervention since effective resolution was mapped out in an influential think tank report that detailed the steps, and budget, necessary to intervene (Wainwright 2003; Bensahel 2008; Fullilove 2006). These requirements were not massive since Solomon Islands is a small state, and had not yet completely collapsed. Feasibility seems especially crucial in cases where a national interest is not directly at stake. Still, despite the plausibility, the individuals involved in the decision that I interviewed almost never articulated a pure humanitarian concern. In reality, although early in the conflict some 35,000 people were displaced, at the intervention point most Solomon Islanders were making due, with outsider assistance for education and health, despite the extortion and occasional violence in the capital, the Weathercoast, and limited regions of Honiara (Fraenkel 2004; Kabutaulaka 2005; Confidential \#5 2008; Downer 2008; Roughan 
2008). If anything, responding to the Ulufa'alu request in 2000 , or an early Sogavare request would have made more sense if this were the motivation. Humanitarian concern, then, is unlikely to be a primary incentive in this case.

Larger strategic concern also has little evidence, especially in Solomon Islands. Hugh White warns in a Defense White Paper in 2000, “Don't take for granted how peaceful great power relations are since Vietnam" (31). There is a possibility that Indonesia or China might move into territory that the Japanese occupied during World War II, and thus threaten Australia if another global conflict began (White 2008). How realistic is this possibility? There is evidence that the Kemakeza government met with the Indonesians about possibly gaining their assistance before RAMSI was enacted (Davis 2003), but, in general, Solomons Islanders had been pleading for help for at least three years, so any country that might have wished to occupy a position there could have offered to do so by then (Cook 2008). There is no Indonesian presence in Solomon Islands, and the Chinese who are engaged in politics there have generally been in the country for generations and are not highly tied to their homeland (Firth and Dinnen 2008). Indeed, Taiwanese aid was a much bigger concern, but not because it stakes out territory in the region, rather because fighting over it led to some of the violence in the country (Fraenkel 2008). There is a bit more Chinese influence in Papua New Guinea, and it is possible that if Australia could not effectively deal with a problem in tiny Solomon Islands, other states, like Papua New Guinea, might seek help elsewhere (White 2008). However, if having China in the region were really Australia's main concern, it would likely have engaged very differently in Fiji, which it sanctioned after the 2006 coup while its stated rival massively increased aid and investment (Cook 2008). Too much foreign influence might harm security interests, according to the region's policy-makers, as even as Downer suggested that he would like China or Indonesia to 
help with the aid burden but only if it did not operate contrary to Australian goals in the region (Downer 2008). There is not much evidence to suggest that this concern drives delegation agreements in Melanesia, though.

Unlike economic interests, humanitarian considerations, or strategic stakes, transnational security concerns are a priority in the region, so this may be an incentive for Australia and its partners in implementing RAMSI. The region mulled over these threats, aside from terrorism, for several years leading to a decision that these states must intervene in their neighbors' affairs when necessary. As early as 1999, the Pacific Island Forum, whose agenda is largely driven by Australia and New Zealand (Firth 2008; Kabutaulaka 2008), suggested that weapons smuggling between countries, as well as "international financial crime, cyber crime, $\mathrm{Y} 2 \mathrm{~K}$ issues, people smuggling, increasing incidents of civil unrest and drug trafficking" are emerging threats that globalism brought to the region ("Thirtieth South Pacific Forum Communique" 1999). "The external threat to the region is posed by crooks in nice suits: drug syndicates using the Pacific as a production and distribution base, passport and identity salesman, people smugglers and money launderers, seeking to use the sovereignty of fragile states to cover criminal dealings across the globe" (Dobell 2008). The forum sought to deal with these concerns, including formalizing the Honiara Initiative to end arms smuggling ("Thirtieth South Pacific Forum Communique" 1999), and, in 2000, creating the Biketawa Declaration that allowed for voluntary intervention requests to bring members of the forum to states needing assistance to ease governance problems. RAMSI was enacted under this declaration ostensibly to deal with these transnational concerns.

The threats identified did not include terrorism, and even 9/11 or the 2002 Bali bombings that killed eighty Australians did not likely change this component of the security assessment in the region. Just before RAMSI, many Australians, such as then Prime Minister John Howard 
described Solomon Islands as a "Petri dish" for transnational threats, including terrorism (Wainwright 2003; cited in Bensahel 2008). Most policy-makers I spoke to, however, recognize that terrorism was highly unlikely to emerge in Solomon Islands (Downer 2008; White 2008; Firth 2008; Hayward-Jones 2008). As one analyst put it, "The Australian Senate report on the southwest Pacific remarked mildly that the potential for terrorists to infiltrate the region was 'debateable" (Dobell 2008). The reason for this is that the weak states coexist with strong societies, and, thus, outsiders could not easily operate inconspicuously (Firth 2008; Roughan 2008). Even with full state failure, this condition would probably not change. Indeed, the only apparent evidence of any terrorism linked to the Pacific Islands are an alleged militant boat captured in the Mediterranean that flew a Tongan flag, and two suspected militants captured in South East Asia who carried Nauru passports (Reilly and Wainwright 2005). Including terrorism among the threats, then, may have been largely a rhetorical flourish that was "a convenient way to remind Aussies of their interests" (Warner 2008), or, more specifically, "a useful argument to explain the dramatic reversal of Pacific policy to the Australian electorate" (Dobell 2008).

Transnational security threats, then, aside from terrorism, may have driven RAMSI, but what explains the timing since this concern existed in the region for a few years before the agreement in 2003 (Wainwright 2003)? Cost concerns likely drove the timing, with regard to a few factors, including actual cost of the mission, international reputational costs, and domestic political costs. As mentioned previously, even when a Melanesian host state requested aid in the midst of highly politicized events, like coups, or perhaps in deeply cleaved societies more generally, the external actor denied them. Many policy-makers I spoke to indicated that this potential cost, for example, was the reason that they opposed engaging in Fiji in 2006, despite the clear breach of democracy there; it would turn into a "shooting war" that Australia could not 
resolve easily (Confidential \#5 2008; Downer 2008). Similar claims explain the decision not to intervene in Solomon Islands after Ulufa'alu's initial request in 2000 (Warner 2008).

The direct cost of the mission was also important in determining when the external actor would agree to delegation. In these cases the alternative against which external actors measured costs was continued monetary aid, rather than armed intervention. The former Australian Foreign Minister suggests that the failure of post-colonial policies, in states without successful public administration, created donor "money pumps" where aid constantly flowed in without much lasting effect. This concern drove his decision to press Papua New Guinea to accept the ECP, so that institutional reform might take place that could make aid more efficient (Downer 2008). Indeed, the 2000-2001 Australian budget shows several hundred million Australian dollars annually contributed to the state, but there is little improvement in development indicators during this period. Solomon Islands did not have nearly the same cost, less than twenty million dollars in the same year, but, if full failure occurred, the requirement could have increased significantly (Wainwright 2003). While this is likely an important concern for policymakers on limited budgets, why would this cause such a radical change of policy in 2003 ? This cost measure may be an explanation for later cases, once RAMSI demonstrated the success of such policy, but it is not likely the initial explanation.

In addition to the direct cost of the mission compared to the appropriate alternative, after 9/11, and especially after the invasion of Iraq, the range of acceptable solutions to problems of state weakness and failure shifted. In particular, these United States decisions may have had a normative impact on international and domestic audiences that changed cost calculations with respect to these influences. The weakness of Melanesian states may have encouraged Australia to consider intervention as early as the 1987 coup in Fiji, but recent colonial experience 
dissuaded such endeavors (White 2008). The timing of the decision to intervene in Solomon Islands, which Australia rejected in January 2003 and then accepted right after major combat operations ended in Iraq later that year (Bensahel 2008; Firth 2008), suggests that international events may have been a consideration that affected the timing of delegation agreements. The intervention seemed specifically aimed at a foreign audience to some extent, as Howard called the meeting that led to RAMSI just after visiting United States President George Bush (Fraenkel 2008). Indeed, in a misquote, Howard had taken on the role of regional "deputy sheriff" for United States in 1999, so this update of policy in line with that pursued by the Bush administration made sense (Kabutaulaka 2005). Australian policy-makers seemed to have been somewhat embarrassed by the possibility of state failure in their own "patch," even if it did not pose a real terrorism threat (Downer 2008; Firth 2008; Fraenkel 2008; White 2008). International opinion, then, may be an important factor here, and, specifically, we may see a domino affect whereby weaker allies in should be willing to engage in these types of agreements with other states after their stronger partners condone such behavior because the reputational cost becomes a benefit.

An alternative reputational cost concerns the domestic audience. Opposition to Howard's close alliance with the United States became quite heated after the invasion of Iraq in March of 2003 (Tow 2004), yet the decision to lead RAMSI was almost unanimous (Downer 2008).

RAMSI, then, may have been viewed as a reengagement of Australia's own interests over those of its allies. Additionally, some claim that the mission aimed to persuade the United States that Australia needed to limit further engagement in the unpopular conflict in Iraq, which played well domestically (Firth 2008; Fry and Kabutaulaka 2008a). After RAMSI's initiation, Howard did use regional engagement to commit fewer troops to the Middle East, as he himself, as well as the 
British Foreign Secretary, Jack Straw, indicated after the allies met (Fry 2008). Domestic appeal may have made this endeavor less costly to Australian politicians, then.

Overall, then, the decision to lead and largely fund RAMSI was likely motivated by Australian transnational security concerns in Solomon Islands. The specific decision to intervene in this state at this time was influenced by cost evaluation. Cost of the mission led Australia to intervene in a moment when the state it chose was not in the midst of an active coup or civil war, and, later, to intervene where aid costs were mounting without effect. Reputational benefits accrued both from responding to crises in the region effectively as engagement became a prized characteristic with its strongest ally, the United States, and from acting independently as the close alliance became a liability domestically. These initial suggestions, then, support the notion that not all external actors will be equally motivated to engage in all states that might request assistance, but they do offer some suggestions for when delegation agreements might emerge.

Thus, more generally, external actors might be motivated to intervene either where a state poses a specific transnational security threat to a particular strong power, which is more likely with the globalization of problems like terrorism and drug production, or where that strong power consistently contributes to aid without any visible progress. Having a reputation for responsibility for a particular region, or for intervention more generally, may also contribute to the likelihood of a delegation agreement, as does a supportive public. These conditions suggest that the hypotheses generated in one region of the world may apply to others. U.S. concern over, and aid to, Liberia, for example, fits many of these conditions, and has recently resulted in a delegation agreement. While this paper generates conclusions in a unique part of the world, then, its hypotheses are ripe for testing around the globe. 
A potential solution for weak or failing states is to enact a delegation agreement. Through case study on Melanesia, this paper concludes that such agreements entail an independent host state relinquishing responsibility over some governance function to a specifically privileged external actor. Treaties, rather than contracts, implement these arrangements, and, in strict rather than semi delegating deals, even grant exemptions or special responsibilities for the external actor in the host's domestic legal apparatus. The Melanesian cases also allow us to generate hypotheses about the conditions under which host states and external actors will enact these self-enforcing equilibria. Specifically, host states in this region request these agreements where either extortion or corruption leads to a budgetary crisis, or where a failure of law and order requires police assistance to re-secure monopoly on force; however, the external actor agrees to them only in the former case since this makes the cost of the mission low, as judged against alternative methods for dealing with such a threat and in terms of reputation, and where such a cost is justified by a specific transnational threat. The next step in this research agenda, then, is to test these hypotheses across cases to see if similar agreements are enacted in other regions, and, if so, if the same incentives also explain the decisions elsewhere. 


\section{APPENDIX 1: Field Interviews}

Name:

Afeau, Primo

Allen, Matthew

Austin, Jonathan

Campbell, Willam "Bill"

Casey, Dawn

Chand, Satish

Cook, Malcolm

Donald, James

Downer, Alexander

Dyer, Sarah

Firth, Stewart

Fraenkel, Jon

Hayward-Jones, Jenny

Hegarty, David

Janosevic, Stevon

Kabutaulaka, Tarcisius Tara

Kenilorea, Peter

Liloqila, Ruth

McDevitt, Ben

Miller, Jeremy

Nolan, Jim

Prescott, Tony

Reilly, Benjamin

Roughan, John

Stone, Emma

Warner, Nick

Wickham, Ashley

White, Hugh

Eight anonymous interviewees
Position:

Location: Date:

Former SI Attorney General

Postdoctoral Fellow, Resource Management in AsiaPacific Program, Research School of Pacific and Asian Studies (RSPAS), Australian National University (ANU)

Deputy Special Coordinator, RAMSI

Honiara, SI 9 9/25/2008

First Assistant Secretary, Office of International Law, AUS Attorney-General's Department

Director, Machinery of Government Program, RAMSI

Associate Professor, Crawford School of Economics and Government, ANU

Program Director, East Asia, Lowy Institute for International Policy

East Timor Section, Asia Bilateral Branch, AusAID

Former AUS Foreign Minister

Solomon Islands National Council of Women

Head, The Pacific Centre, RSPAS, ANU

Fellow, State, Society and Governance in Melanesia Program (SSGM), RSPAS, ANU

Program Director, The Myer Foundation Melanesia Program, Lowy Institute for International Policy

Former Leader of the IMPT; Convener and Senior Fellow, SSGM, RSPAS, ANU

Rove Prison Official

Author on Melanesia; Fellow, Pacific Islands

Development Program, East-West Center

Former SI Prime Minister

Permanent Secretary to SI Parliament

Former Commander of the RAMSI police force, and Former Deputy Commissioner of the RSIP

Public Affairs Officer, RAMSI

Catholic Priest

Anti-Corruption Coordinator, RAMSI

Director, Center for Democratic Institutions, ANU

Former Secretary to the SI Prime Minister (Sogavare)

AusAID

Former Special Coordinator, RAMSI; Current Head of the Defence Department

Analyst in the SI Prime Minister's office

Director, Strategic and Defense Studies Center, ANU
Honiara, SI 9/25/2008

Canberra, AUS 9/9/2008

Honiara, SI 9/25/2008

Canberra, AUS 9/10/2008

Sydney $\quad 9 / 15 / 2008$

Canberra, AUS 9/11/2008

Adelaide, AUS 9/18/2008

Honiara, SI 9/24/2008

Sydney, AUS 9/16/2008

Honiara, SI 9/24/2008

Sydney, AUS 9/15/2008

Canberra, AUS 9/8/2008

Honiara, SI 9 9/25/2008

Honiara, SI 9/25/2008

Honiara, SI 9/25/2008

Honiara 9/23/2008

Darwin, AUS 9/10/2008

Honiara, SI 9 9/25/2008

Honiara, SI 9/25/2008

Honiara, SI 9/24/2008

Canberra, AUS 9/11/2008

Honiara, SI 9/24/2008

Canberra, AUS 9/12/2008

Canberra, AUS 9/8/2008

Honiara, SI 9 9/24/2008

Canberra, AUS 9/9/2008

AUS, SI $\quad 9 / 2008$
Canberra, AUS 9/12/2008 
Work Cited

Afeau, Primo. 2008. Personal Interview. Honiara, 25 September.

"Agreement Between Australia and Nauru Concerning Additional Police and Other Assistance to Nauru." 2004. Melbourne.

"Agreement between Solomon Islands, Australia, New Zealand, Fiji, Papua New Guinea, Samoa and Tonga." 2003. In 17, ed. D. o. F. A. a. Trade. Townsville: Australian Treaty Series.

Allen, Matthew. 2006. "Dissenting voices: local perspectives on the Regional Assistance

Mission to Solomon Islands." Pacific Economic Bulletin 21 (2): 194-201.

Anderson, Tim. 2008. "The Limits of RAMSI." Sydney: AidWatch.

"Aussie to Head Fiji Police." 2003. New Zealand Radio International.

Austin, Jonathan. 2008. Personal Interview. Honiara, 25 September.

Australian Solomons Gold Limited. October 2008. [cited October 2008]. Available from http://www.solomonsgold.com.au/goldridge.php.

Barrett, David B., George T. Kurian, and Todd M. Johnson. 2001. World Christian Encyclopedia. Oxford: Oxford University Press.

Bates, Robert H. 1983. "Modernization, Ethnic Competition and the Rationality of Politics in Contemporary Africa." In State Versus Ethnic Claims: African Policy Dilemmas, ed. D. Rothchild and V. Olorunsola. Boulder: Westview.

Bennett, Judith A. 1987. Wealth of the Solomons: A History of a Pacific Archipelago, 18001978. Honolulu: University of Hawaii Press.

- 2002. Roots of Conflict in Solomon Islands: Though Much is Taken, Much Abides-Legacies of Tradition and Colonialism. Canberra: Research School of Pacific and Asian Studies, Australian National University.

Bensahel, Nora. 2008. "Solomon Islands." In Europe's Role in Nation-Building: From the Balkins to the Congo. Santa Monica: RAND Corporation.

Boone, P. 1996. "Politics and the effectiveness of foreign aid." European Economic Review 40 (2): 289-329.

Burnside, C., and D. Dollar. 2000. "Aid, Policy and Growth." American Economic Review 90 (4): 847-68.

Campbell, William "Bill". 2008. Personal Interview. Canberra, 12 September.

Chand, Satish. 2008. Personal Interview. Canberra, 10 September.

Chand, Satish, and Theodore Levantis. 2000. "Dutch Disease and the Crime Epidemic: An Investigation of the Mineral Boom in Papua New Guinea." The Australian Journal of Agricultural and Resource Economics 44 (1): 129-46.

Chesterman, Simon, Michael Ignatieff, and Ramesh C. Thakur. 2005. "The Future of StateBuilding." In Making States Work: State Failure And The Crisis Of Governance, ed. S. Chesterman, M. Ignatieff and R. C. Thakur. Tokyo: United Nations University Press.

Collier, P. 1997. "The Failure of Conditionality." Perspectives on Aid and Development: 51-77. Confidential \#5, Government Source. 2008. Canberra, 10 September.

Confidential \#10 \& 11, Government Sources. 2008. Canberra, 12 September.

Cook, Malcolm. 2008. Personal Interview. Sydney, 15 September.

Davis, Mark. 2003. Solomons Riddle. Sydney.

Dinnen, Sinclair. 2000. "Breaking the Cycle of Violence: Crime and State in Papua New Guinea." In Developing cultural criminology: theory and practice in Papua New Guinea, ed. C. Banks. Sydney: Sydney Institute of Criminology Monograph Series. 
. 2002. "Winners and Losers: Politics and Disorder in the Solomon Islands 2000-2002." The Journal of Pacific History 37 (3): 285-98.

. 2008. "Dilemmas of Intervention and the Building of State and Nation." In Politics and State Building in Solomon Islands, ed. S. Firth and S. Dinnen. Canberra: Asia Pacific Press.

Dinnen, Sinclair, Abby McLeod, and Gordon Peake. 2006. "Police-Building in Weak States: Australian Approaches in Papua New Guinea and Solomon Islands." Civil Wars 8 (2): $87-108$.

Dobbins, James. 2003. America's Role in Nation-Building: From Germany to Iraq. Santa Monica: RAND Corporation.

Dobbins, James, Seth G. Jones, Keith Crane, Christopher S. Chivvis, Andrew Radin, F. Stephen Larrabee, Nora Bensahel, Brooke Stearns Lawson, and Benjamin W. Goldsmith. 2008. Europe's Role in Nation-building: From the Balkans to the Congo. Santa Monica: RAND Corporation.

Dobbins, James, Seth G. Jones, Keith Crane, Andrew Rathmell, Brett Steele, Richard Teltschik, and Anga Timilsina. 2005. The UN's Role in Nation-Building from the Congo to Iraq. Santa Monica: RAND Corporation.

Dobell, Graeme. 2008. "Australia's Intervention Policy: A Melanesian Learning Curve?" In Intervention and State-building in the Pacific: The Legitimacy of 'Co-operative Intervention', ed. G. Fry and T. T. Kabutaulaka. Manchester: Manchester University Press.

Downer, Alexander. 2008. Personal Interview. Adelaide, 18 September.

Esty, D. C., J. A. Goldstone, T. R. Gurr, B. Harff, M. Levy, G. D. Dabelko, P. T. Surko, and A. N. Unger. 1998. "State Failure Task Force Report: Phase II Findings." McLean, VA: Science Applications International Corporation.

Fearon, James D. 2002. "Ethnic Structure and Cultural Diversity around the World: A CrossNational Data Set on Ethnic Groups." Stanford: Stanford University.

Fearon, James D., and David D. Laitin. 2003. "Ethnicity, Insurgency, and Civil War." American Political Science Review 97 (1): 75-90.

_ 2004. "Neotrusteeship and the Problem of Weak States." International Security 28 (4): $5-43$.

Feigenbaum, Harvey B., and Jeffrey R. Henig. 1994. "The Political Underpinnings of Privatization: A Typology." World Politics 46 (2): 185-208.

"Fiji Probe of Former Police Commissioner's Role in 2000 Coup Incomplete." 2003. New Zealand Radio International.

Firth, Stewart. 2008. Personal Interview. Sydney, 16 September.

Firth, Stewart, and Sinclair Dinnen. 2008. Politics and State Building in Solomon Islands. Canberra: Asia Pacific Press.

"Focus-ECP's Legal Fallout on Immunity." 2005. Papua New Guinea Post-Courier, 19 May.

Forbes, Mark. 2003. "Thanks for the Refugee Camps, Nauru, How Would You Like To Be Australian?" Sydney Morning Herald, 19 December.

Fraenkel, Jon. 2004. The Manipulation of Custom: From Uprising to Intervention in the Solomon Islands. Wellington: Victoria University Press.

- 2008. Personal Interview. Honiara, 24 September. 
Fry, Greg. 2008. "'Our Patch': The War on Terror and the New Interventionism." In Intervention and State-building in the Pacific: The Legitimacy of 'Co-operative Intervention', ed. G. Fry and T. T. Kabutaulaka. Manchester: Manchester University Press.

Fry, Greg, and Tarcisius Tara Kabutaulaka. 2008a. Intervention and State-building in the Pacific: The Legitimacy of 'Co-operative Intervention'. Manchester: Manchester University Press.

—. 2008b. "Political Legitimacy and State-building Intervention in the Pacific." In Intervention and State-building in the Pacific: The Legitimacy of 'Co-operative Intervention', ed. G. Fry and T. T. Kabutaulaka. Manchester: Manchester University Press.

Fukuyama, Francis. 2004. State-Building: Governance and World Order in the 21st Century. Ithaca, N.Y.: Cornell University Press. . 2007a. "Governance Reform in Papua New Guinea." Washington, D.C.: SAIS. SAIS.

- 2008. "State-Building in the Solomon Islands." Washington, D.C.: World Bank.

Fullilove, Michael. 2006. "The Testament of the Solomons: RAMSI and International StateBuilding." Sydney: Lowy Institute for International Policy.

Garran, Robert, and Mary-Louise O'Callaghan. 2000. "Fiji...Solomon Islands...Is PNG the Next Domino?" The Australian, 9 June.

Girod, Desha M. 2007. "Why Being Resource Poor Helps Postwar Development." Stanford: Stanford University.

Goldstein, Judith O., Miles Kahler, Robert Keohane, and Anne-Marie Slaughter. 2000. "Introduction: Legalization and World Politics " International Organization 54 (3): 38599.

Goldstone, J. A., T. R. Gurr, B. Harff, M. A. Levy, M. G. Marshall, R. H. Bates, D. L. Epstein, C. H. Kahl, P. T. Surko, and J. C. Ulfelder Jr. 2000a. "State Failure Task Force Report: Phase III Findings." McLean, VA: Science Applications International Corporation 30.

Goldstone, Jack A., Ted R. Gurr, Barbara Harff, Marc A. Levy, Monty G. Marshall, Robert H. Bates, David L. Epstein, Colin H. Kahl, Pamela T. Surko, and John C. Ulfelder Jr. 2000b. "State Failure Task Force Report: Phase III Findings." McLean, VA: Science Applications International Corporation.

Hawk, Kathleen H. 2002. Constructing the Stable State: Goals for Intervention and Peacebuilding. Westport: Greenwood Publishing Group.

Hayward-Jones, Jenny. 2008. Personal Interview. Sydney, 15 September.

Hegarty, David. 2008. Personal Interview. Canberra, 8 September.

Helman, G. B., and S. R. Ratner. 1992. "Saving Failed States." Foreign Policy: 3-20.

Herbst, Jeffrey. 2000. States and Power in Africa: Comparative Lessons in Authority and Control. Princeton, NJ: Princeton University Press.

"Human Development Report." 2007/2008. New York: United Nations. Jackson, Robert. 2007. Sovereignty: Evolution of an Idea. Cambridge: Polity Press.

"Joint Agreement on Enhanced Cooperation Between Australia and Papua New Guinea." 2004. In 24, ed. D. o. F. A. a. Trade. Port Moresby: Australian Treaty Series.

Kabutaulaka, Tarcisius Tara. 2005. "Australian Foreign Policy and the RAMSI Intervention in Solomon Islands." CONTEMPORARY PACIFIC 17 (2): 283. . 2008. Personal Interview. Honiara, 25 September. 
Kaplan, Oliver. 2006. "International Organizations and the Custom of Outsourcing Customs." In Annual Meeting of the American Political Science Association. Philadelphia, PA.

Kenilorea, Peter. 2008. Personal Interview. Honiara, 25 September.

Keohane, Robert O. 2003. "Political Authority after Intervention: Gradations in Sovereignty." In Humanitarian Intervention: Principles, Institutions and Change, ed. J. L. Holzgrefe and R. O. Keohane. Cambridge: Cambridge University Press.

King, Gary, and Langche Zeng. 2001. "Improving Forecasts of State Failure." World Politics 53 (4): 623-58.

Krasner, Stephen D. 1999. Sovereignty: Organized Hypocrisy. Princeton: Princeton University Press.

_. 2004. "Sharing Sovereignty: New Institutions for Collapsed and Failing States." International Security 29 (2): 85-120.

Krause, Keith. 1996. "Insecurity and State Formation in the Global Military Order:: The Middle Eastern Case." European Journal of International Relations 2 (3): 319.

Lake, David A. 1999. Entangling Relations: American Foreign Policy in Its Century. Princetons: Princeton University Press.

"Leaving Nauru Not an Option: President." 2003. Canberra Times, 20 December.

Liloqila, Ruth. 2008. Personal Interview. Honiara, 23 September.

McDevitt, Ben. 2008. Personal Email. Canberra, 10 September.

Milliken, Jennifer, and Keith Krause. 2002. "State Failure, State Collapse, and State Reconstruction: Concepts, Lessons and Strategies." Development and Change 33 (5): 753-74.

Moore, Clive. 2005. Happy Isles In Crisis: The Historical Causes for a Failing State in Solomon Islands, 1998-2004. Canberra: Asia Pacific Press.

Nolan, Jim. 2008. Personal Interview. Honiara, 25 September.

O'Callaghan, Mary-Louise. 2000. "Solomons Plead for Military Aid." The Australian, 8 June.

O'Connor, Tim. 2003. "Briefing Paper: Solomon Islands--Should Australia Send Peace Keeping Force?" Sydney: AidWatch.

Ottaway, Marina. 2002. "Rebuilding State Institutions in Collapsed States." Development and Change 33 (5): 1001-23.

"Ousted Aussie Police Chief Returns To Ranks." 2006. Fiji Times, 3 January.

Paris, Roland. 2004. At War's End: Building Peace After Civil Conflict. Cambridge: Cambridge University Press.

Passey, Megan. 1996. "Issues in the Management of Sexually Transmitted Diseases in Papua New Guinea." Papua New Guinea Medical Journal 39 (3): 252.

PNG Sustainable Development Program Limited [cited October 2008. Available from http://www.pngsdp.com/companyprofile/.

Reilly, Benjamin. 2001. "Democracy, Ethnic Fragmentation, and Internal Conflict: Confused Theories, Faulty Data, and the \&\#x201C;Crucial Case\&\#x201D; of Papua New Guinea." International Security 25 (3): 162-85.

. 2008. Personal Interview. Canberra, 11 September.

Reilly, Benjamin, and Elsina Wainwright. 2005. In Making States Work: State Failure And The Crisis Of Governance, ed. S. Chesterman, M. Ignatieff and R. C. Thakur. Tokyo: United Nations University Press.

Reno, William. 1999. Warlord Politics and African States. Boulder: Lynne Rienner Publishers. Roughan, John. 2008. Personal Interview. Honiara, 24 September. 
Scott, Ben. 2005. "Re-Imagining PNG: Culture, Democracy and Australia's Role." Sydney: Lowy Institute.

Solomon, Islands National Parliament. 2003. "Facilitation of International Assistance Act, Sessional Legislation." Honiara.

Stewart, Rod. 2006. "An Economic Survey of Developing Countries in the Pacific Region." In Economic Roundup. Canberra: Treasury.

Svensson, J. 2003. "Why conditional aid does not work and what can be done about it." Journal of Development Economics 70 (2): 381-402.

"Thirtieth South Pacific Forum Communique." 1999. Koror, Palau.

Tow, William T. 2004. "Deputy Sheriff or Independent Ally? Evolving Australian-American Ties in an Ambiguous World Order." The Pacific Review 17 (2): 271-90.

Vulum, Sam. 2005. "PNG's Luther Wenge: A Champion Among His People." Islands Business Magazine, 30 June.

Wainwright, Elsina. 2003. "Our Failing Neighbor: Australia and the Future of the Solomon Islands." Canberra: Australian Strategic Policy Institute.

Warner, Nick. 2008. Personal Interview. Canberra, 8 September.

"Wenge to Test ECP's Validity in Court." 2004. Papua New Guinea Post-Courier, 20 July.

White, Hugh. 2008. Personal Interview. Canberra, 9 September.

Wickham, Ashley, and John Roughan. 2008. Personal Interview. Honiara, 24 September.

Zaller, John. 1994. "Elite Leadership of Mass Opinion: New Evidence from the Gulf War." In Taken by Storm: The Media, Public Opinion and US Foreign Policy in the Gulf War, ed. W. L. Bennett and D. L. Paletz. Chicago, I.L.: The University of Chicago.

Zartman, I. William. 1995. Collapsed States: The Disintegration and Restoration of Legitimate Authority. Boulder, C.O.: Lynne Rienner Publishers.

Zuercher, Christoph. 2006. "When Governance Meets Troubled States-DRAFT." In Staatszerfall und Governance, ed. M. Beisheim/Thomas. 